\title{
PLANET OF THE FIVE RINGS
}

\author{
It's a dream come true.
}

\section{BY MARISSA LINGEN}

$\mathrm{T}$ he alien was bipedal, faintly yellowgreen, awkward. By no means was this a little green man; it gallumphed down the ramp of the spaceship, seven feet of bulbous awkwardness clothed in slightly shiny trousers and ... it was probably still a shirt of some sort if it encased multiple arms? Andrea Cho, UN linguist, did not let herself get sidetracked into clothing semantics.

She held her breath, at first in excitement and after a moment because she had caught a whiff of the esterrich interior of the spaceship. She made herself breathe. She had trained for this all her life. A sudden middle-of-thenight flight to Athens, where the ship had landed, had left her exhausted and keyed up.

"Okay," she said to her team quietly, "you know the protocols."

"Hi, Katie!" said the alien. "It's an honour just to be here. I've imagined this day since I was only a little kid, and now that I'm here, it's more than I could ever have dreamed of."

The entire UN linguistics team froze. None of them was named Katie, but that seemed like a tiny point under the circumstances. Andrea was the first to recover. "You ... speak English."

"Of course! We learned from your broadcasts, one every two orbits of your Sun."

The linguists looked at each other, puzzled. Andrea forged on. "Where do you come from?"

"It's a small town where everyone knows everyone. After my parent died when I was but a spawn, the kind people of my town supported me in pursuing my goals of someday getting here. And here I am! It's like a dream come true."

Andrea hoped that the alien had not learned to read human facial expressions along with the English language, because she could feel that she looked like she had bitten into a lemon. "Let's focus on the astrophysics for a minute: how did you get here?"

"Well, Katie, I followed my dreams and worked tirelessly day and night. I think I wanted it more than anyone else."

"My name's not Katie. And I was hoping for more about the mechanics."

"It was a big dream. I had a lot of support in making it happen. Also, my apologies; I thought 'Katie' was a generic form of address

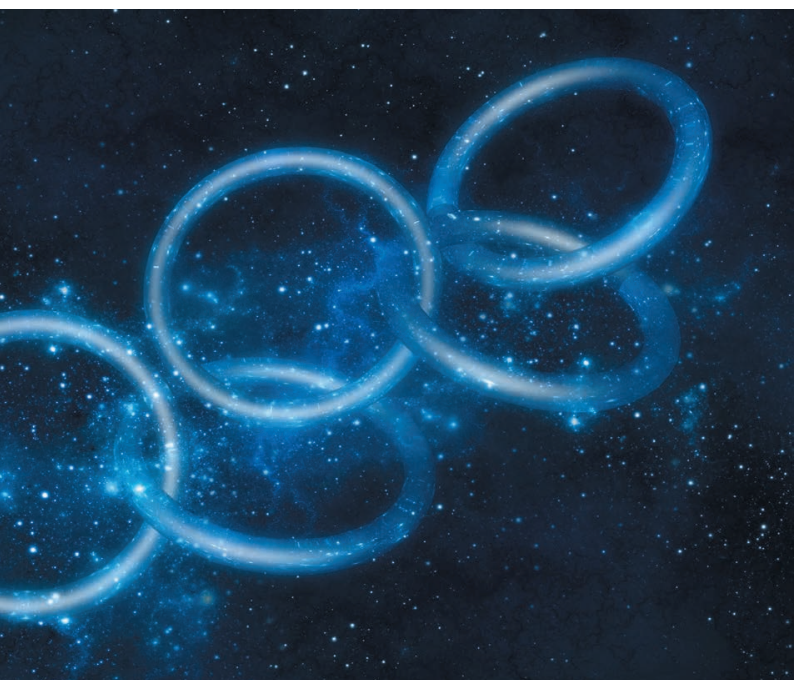

kinds of stars, planets, fuel. She was the most technically literate linguist on the planet, at the head of a team of people only half a beat behind her.

She had no idea when Jamaica had first fielded a bobsledding team. She had never thought it would be important.

"We know that these are your legends," said the alien patiently, "because you cannot let a broadcast on these subjects go by without mentioning them. Nadia Comăneci and Béla Károlyi! Miracle on Ice!"

"Right back atcha," said Andrea weakly. "Look, it would really mean a lot to my, uh, my coach if you could tell me some things about where you come from, who you are."

"We will have plenty of time for these things," said the alien. "But you must first tell me: can we get tickets to the

for all Earth females when asking questions." "It isn't."

"Oh. Are all Earth males known as Bob in that circumstance?"

"No!"

"Oh."

Andrea waited for a long moment and then finally burst out, "What broadcasts did you learn from, exactly?"

"The games of the twenty-eighth through fortieth Olympiads, inclusive!" The alien paused to turn its head in a semicircle, baring its teeth in a way that Andrea would have found alarming ... if she hadn't seen it done a million times by gymnasts and figure skaters. She wondered with what felt like a flash of madness what aliens used for Vaseline on their teeth.

"Okay," said Andrea softly, "okay, wow."

"We would like to see all of your major Earth sites, for example the velodrome and the stunning aquatic centre," said the alien. "A smaller number of us are also excited to see the luge track and the ski jump. Eddie the Eagle! Jamaican bobsled team!"

"That... I think that was before the twenty-eighth Olympiad," said Andrea. She $\rightarrow$ NATURE.COM

Follow Futures: $\checkmark$ @NatureFutures f go.nature.com/mtoodm with basic maths to try to communicate. She had learnt vocabulary for different beach volleyball? I hear that is the must-see event. Very difficult."

"For you? We can try to work something out. Especially if you can tell us how your interstellar drive works." The alien hesitated. Andrea gritted her teeth and played her trump card. "Bringing interstellar drive to humans is a dream I've had since I was a little girl," she lied. "I've trained so hard for this moment. If you can be part of the team, stand with me on the top step of the podium -"

"Of course! We will be champions together!" The alien flashed its shiny teeth in a semicircle again and raised its arms in a victory $\mathrm{V}$. Andrea, still trying to think through the implications, thought that her role might be to clap wildly. She tried it.

The alien hugged her. Andrea found herself enveloped in four arms, choking down an even stronger cloud of esters, pressed against the shiny material that, now that she had the context, looked remarkably like tracksuit fabric. The alien released her and went on to hug each member of the team in turn. They all smiled through the stench as though their teeth were smeared with Vaseline.

Marissa Lingen has published more than 100 short stories in venues such as Analog, Lightspeed and Tor.com. 